\title{
Fibrosis: recent advances in myofibroblast biology and new therapeutic perspectives Boris $\mathrm{Hinz}^{1 *}$ and Giulio Gabbiani ${ }^{2}$
}

\author{
Addresses: ${ }^{1}$ Laboratory of Tissue Repair and Regeneration, Matrix Dynamics Group, Faculty of Dentistry, University of Toronto, 150 College \\ Street, Toronto, ON M5S 3E2, Canada; ${ }^{2}$ Department of Pathology and Immunology, CMU, University of Geneva, Rue Michel-Servet 1 , \\ 1211 Switzerland \\ * Corresponding author: Boris Hinz (boris.hinz@utoronto.ca) \\ FI000 Biology Reports 2010, 2:78 (doi:10.34I0/B2-78) \\ This is an open-access article distributed under the terms of the Creative Commons Attribution-Non Commercial License \\ (http://creativecommons.org/licenses/by-nc/3.0/legalcode), which permits unrestricted use, distribution, and reproduction in any medium, \\ provided the original work is properly cited. You may not use this work for commercial purposes. \\ The electronic version of this article is the complete one and can be found at: http://f1000.com/reports/b/2/78
}

\begin{abstract}
The crucial role of the myofibroblast in wound healing and fibrosis development is well established. This review discusses the mechanisms of myofibroblast action and the new findings that may develop into therapeutic strategies during the next few years.
\end{abstract}

\section{Introduction and context}

Tissue destruction by organ fibrosis contributes to the lethal outcomes associated with heart, lung, liver, kidney, and skin diseases. The cell responsible for the detrimental fibrotic tissue contractures is the myofibroblast, which has a phenotype characterized by excessive production of collagenous extracellular matrix (ECM) and tensile force [1]. The concept that the myofibroblast plays a pivotal role in the establishment of fibrotic conditions has paved the way for a new approach in the understanding of the mechanisms of these pathologic situations [2]. In particular, it has become accepted that mechanical force generation by myofibroblasts, which in turn depends on the neo-expression of $\alpha$-smooth muscle actin ( $\alpha$-SMA) in stress fibers of these cells, regulates essential phenomena for tissue remodeling, such as cytokine synthesis and ECM component production [2]. The myofibroblast participates in a variety of phenomena, including embryologic development, organ fibrosis, and the stroma reaction to epithelial tumors [1]. This widespread occurrence suggests that the term myofibroblast describes a functional status rather than a fixed cell type. This assumption has been supported by recent findings indicating that myofibroblasts originate from a spectrum of cellular sources depending on the physiological or pathological situation [1]. Myofibroblast origin and its tissue environment should be considered when planning new therapeutic strategies that aim at decreasing myofibroblast number or activity.

\section{Major recent advances}

The list of cells from which myofibroblasts can derive has grown impressively during the last years. It includes local fibroblasts, epithelial cells, endothelial cells, smooth muscle cells, pericytes, hepatic perisinusoidal cells, mesenchymal stem cells, and bone marrow-derived cells known as fibrocytes $[1,3]$. Most attention has been given to the fibrocyte as a possible myofibroblast precursor [4] and the phenomena of epithelial- and endothelial-mesenchymal transition as myofibroblast sources, particularly during lung and kidney fibrosis $[5,6]$. Transition of epithelial cells all the way to the myofibroblast phenotype is inducible in culture and regulated by different signaling pathways $[7,8]$. However, the relative contribution of myofibroblast precursors remains to be determined. As one would intuitively expect, it appears likely that in most situations local fibroblasts represent the major source of myofibroblasts [1]. The local derivation of myofibroblasts from mesenchymal rather than epithelial or endothelial cells has recently been documented in a model of renal interstitial fibrosis by means of genetic lineage tracing [9].

At present there is no accepted therapy for fibrotic diseases [10]. A number of previous and recent antifibrotic strategies attempt to interfere with myofibroblast formation by targeting key factors in the differentiation process (Figure 1). It is well established that myofibroblast 
differentiation and organ fibrosis are predominantly controlled by transforming growth factor $\beta 1$ (TGF- $\beta 1$ ) [11] and the ED-A (extra domain A) found in cellular fibronectin [12]. Moreover, several cytokines and chemokines (and their receptors), as well as coagulation factors and ECM components, have been implicated in this process [13-18]. It is likely that the heterogeneity of the myofibroblast origin requires specific factors and specific mechanical conditions in each situation.

Fibrosis is usually diagnosed when tissue destruction is already progressing, and it is possible that therapies will have to target the resident myofibroblast population. For this, aiming at the contractile apparatus is allegedly the most straight forward and promising strategy to inhibit myofibroblast function (Figure 1). A new direction, which has proven experimentally successful, is based on the observation that intracellular delivery of the $\alpha$-SMA amino-terminal sequence Ac-EEED inhibits the incorporation of this protein in myofibroblast stress fibers, thus reducing force production as well as collagen type I synthesis by myofibroblasts in vitro; moreover, it significantly inhibits experimental wound contraction in vivo [19]. Due to its relative specificity for $\alpha$-SMAexpressing myofibroblast stress fibers, this peptide appears as a good candidate for topical (e.g., burn scars) and systemic (e.g., organ fibrosis) administration.

Another promising strategy to induce myofibroblast disappearance is to stimulate them to go into apoptosis. Two major intracellular pathways have been identified that act pro-survival (or anti-apoptotic) for the myofibroblast: focal adhesion kinase signaling in cell ECM adhesions and phosphatidylinositol 3-kinase (PI3K)-AKT signaling. Focal adhesion kinase activation protects myofibroblasts from going into apoptosis in response to the loss of cell adhesion, a phenomenon called anoikis [20]. TGF- $\beta 1$ and endothelin-1 have been shown to independently

Figure I. Targeting the myofibroblast

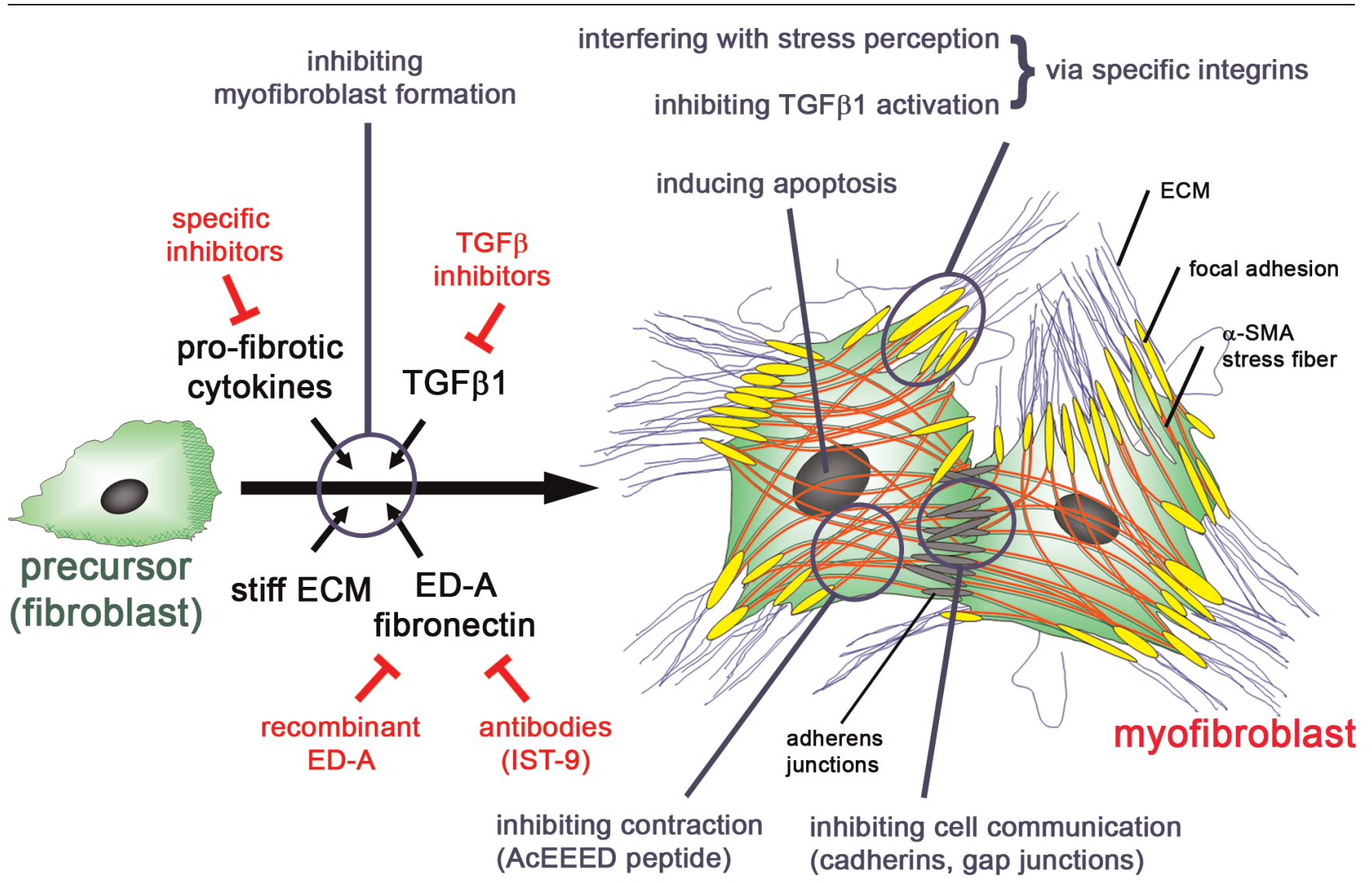

Potential antifibrotic therapies can interfere with the chemical and mechanical factors that lead to myofibroblast formation from different precursor cells (shown here for fibroblasts). Alternatively, or additionally, specific features of the differentiated myofibroblast can be targeted to induce myofibroblast regression and/or apoptosis. $\alpha$-SMA, alpha-smooth muscle actin; ECM, extracellular matrix; ED-A, extra domain A; IST-9; fibronectin antibody; TGF 3 I, transforming growth factor $\beta \mathrm{I}$. 
activate the PI3K-AKT pathway and thereby render myofibroblasts apoptosis-resistant [21]. Development of protein kinase inhibitors as specific inducers of myofibroblast apoptosis is an exciting new avenue in fighting fibrosis [22]. Other strategies could include myofibroblastspecific delivery of apoptosis-inducing drugs as applied in a mouse model of liver fibrosis [23].

Inducing myofibroblast disappearance does not necessarily include their killing; interrupting the auto/paracrine production of active TGF- $\beta 1$ leads to myofibroblast de-differentiation, at least in vitro [24]. However, attempts to use general inhibitors of TGF- $\beta 1$ have been relatively unsuccessful, showing that fibrosis development is a more complex phenomenon than expected [25-28]. The limitation of such global strategies is the interference of the beneficial effects of the pleiotrophic TGF- $\beta 1$, such as controlling homeostasis of epithelial, vascular, endothelial, and immune cells. Therefore, more promising strategies may be to prevent latent TGF- $\beta 1$ activation in a cell-type-specific manner rather than blocking already active TGF- $\beta 1$. TGF- $\beta 1$ is secreted together with LAP (latency-associated peptide), forming a large complex with latent TGF- $\beta 1$ binding protein 1 (LTBP-1) in the ECM [29]. Epithelial cells activate latent TGF- $\beta 1$ via integrin $\alpha v \beta 6[30,31]$, which requires ECM binding mediated by LTBP-1 [29]. Inhibition of the epithelium-specific av $\beta 6$ integrin protects from lung, kidney, and bile duct fibrosis [32-35]. In addition, integrins $\alpha v \beta 3, \alpha v \beta 8$, and $\alpha v \beta 5$ play a role in latent TGF- $\beta 1$ activation by fibroblastic cells, either directly or in a process involving proteases [11,36-40]. We have described a novel mechanical mechanism of latent TGF$\beta 1$ activation for myofibroblasts that, literally, pulls on the large latent complex using the integrin $\alpha \mathrm{v} \beta 5$ [41].

\section{Future directions}

Blocking specific integrins is a promising future strategy to control the development of myofibroblasts in fibrotic disorders (Figure 1). In addition to blocking the latent TGF- $\beta 1$-activating integrin $\alpha \mathrm{v} \beta 5$ [41-44], inhibition of integrin $\alpha 3[8,45], \alpha 11,[46] \quad \alpha v \beta 3$ $[44,47]$, and $\beta 1$ [48] were shown to block myofibroblast development and may be developed into future therapies. The latter integrins are all implicated in myofibroblast mechanoperception and transduction. It becomes increasingly clear that myofibroblast differentiation crucially depends on mechanical factors such as ECM stiffness and intracellular tension. Mechanical stress determines the stress fiber localization of $\alpha$-SMA [49], modulates $\alpha$-SMA promoter activity and protein expression in a process that involves the myocardinrelated transcription factor $[7,48,50]$, and modulates the bioactivity of TGF- $\beta 1$ [41]. Hence, releasing myofibroblasts from stress - for example, using the Ac-EEED peptide [51] - will have a profound and longterm effect on myofibroblast persistence and may even induce myofibroblast apoptosis [52].

\section{Abbreviations}

$\alpha$-SMA, alpha-smooth muscle actin; ECM, extracellular matrix; PI3K, phosphatidylinositol 3-kinase; LTBP-1, latent transforming growth factor $\beta 1$ binding protein 1 ; TGF- $\beta 1$, transforming growth factor $\beta 1$.

\section{Competing interests}

The authors declare that they have no competing interests.

\section{Acknowledgements}

The work of $\mathrm{BH}$ is supported by grants from the Swiss National Science Foundation (grant\# 3100A0-113733/1), the Heart and Stroke Foundation Ontario (grant\# NA7086), and the Canadian Institutes of Health Research (grant\# 210820).

\section{References}

I. Hinz B, Phan SH, Thannickal VJ, Galli A, Bochaton-Piallat ML, Gabbiani G: The myofibroblast: one function, multiple origins. Am J Pathol 2007, I70:1807-16.

2. Tomasek JJ, Gabbiani G, Hinz B, Chaponnier C, Brown RA: Myofibroblasts and mechano-regulation of connective tissue remodelling. Nat Rev Mol Cell Biol 2002, 3:349-63.

3. Hinz B: The myofibroblast in connective tissue repair and regeneration. In Regenerative Medicine and Biomaterials for the Repair of Connective Tissues. Edited by Ralphs CAJ. Cambridge, UK: Woodhead Publishing Ltd; 2010: 39-82.

4. Herzog EL, Bucala R: Fibrocytes in health and disease. Exp Hematol 2010, 38:548-56.

5. Thiery JP, Acloque H, Huang RY, Nieto MA: Epithelial-mesenchymal transitions in development and disease. Cell 2009, |39:87|-90.

6. Kalluri R, Weinberg RA: The basics of epithelial-mesenchymal transition. J Clin Invest 2009, I I9:|420-8.

7. Masszi A, Speight P, Charbonney E, Lodyga M, Nakano H, Szaszi K, Kapus A: Fate-determining mechanisms in epithelialmyofibroblast transition: major inhibitory role for Smad3. J Cell Biol 2010, 188:383-99.

8. Kim KK, Wei Y, Szekeres C, Kugler MC, Wolters PJ, Hill ML, Frank JA, Brumwell AN, Wheeler SE, Kreidberg JA, Chapman HA: Epithelial cell alpha3betal integrin links beta-catenin and Smad signaling to promote myofibroblast formation and pulmonary fibrosis. J Clin Invest 2009, I 19:2 I 3-24.

FI000 Factor 6

Evaluated by Giulio Gabbiani 23 Jan 2009

9. Humphreys BD, Lin SL, Kobayashi A, Hudson TE, Nowlin BT, Bonventre JV, Valerius MT, McMahon AP, Duffield JS: Fate tracing reveals the pericyte and not epithelial origin of myofibroblasts in kidney fibrosis. Am J Pathol 2010, I76:85-97.

FI000 Factor 10 Evaluated by Giulio Gabbiani 22 Dec 2009, Gregory Dressler 04 Jan 2010

10. Ryu JH, Daniels CE: Advances in the management of idiopathic pulmonary fibrosis. Fl000 Med Rep 2010, 2:28. 
1I. Wipff PJ, Hinz B: Integrins and the activation of latent transforming growth factor betal - an intimate relationship. Eur J Cell Biol 2008, 87:60I-I5.

12. Muro AF, Moretti FA, Moore BB, Yan M, Atrasz RG, Wilke CA, Flaherty KR, Martinez FJ, Tsui JL, Sheppard D, Baralle FE, Toews GB, White ES: An essential role for fibronectin extra type III domain A in pulmonary fibrosis. Am J Respir Crit Care Med 2008, I77:638-45.

13. Yates CC, Krishna P, Whaley D, Bodnar R, Turner T, Wells A: Lack of CXC chemokine receptor 3 signaling leads to hypertrophic and hypercellular scarring. Am J Pathol 2010, 176: 1743-55.

FI000 Factor 8

Evaluated by Giulio Gabbiani 16 Mar 2010

14. Bogatkevich GS, Ludwicka-Bradley A, Silver RM: Dabigatran, a direct thrombin inhibitor, demonstrates antifibrotic effects on lung fibroblasts. Arthritis Rheum 2009, 60:3455-64.

FI000 Factor 6

Evaluated by Giulio Gabbiani 02 Dec 2009

15. Simpson RM, Meran S, Thomas D, Stephens P, Bowen T, Steadman R, Phillips A: Age-related changes in pericellular hyaluronan organization leads to impaired dermal fibroblast to myofibroblast differentiation. Am J Pathol 2009, 175:1915-28.

FI000 Factor 8

Evaluated by Giulio Gabbiani 16 Oct 2009

16. Asano $Y$ : Future treatments in systemic sclerosis. J Dermatol 2010, 37:54-70

17. Webber J, Jenkins RH, Meran S, Phillips A, Steadman R: Modulation of TGFbetal-dependent myofibroblast differentiation by hyaluronan. Am J Pathol 2009, 175: 148-60.

FI000 Factor 6

Evaluated by Steve Lye 22 Sep 2009

18. Liu T, Hu B, Choi YY, Chung M, Ullenbruch M, Yu H, Lowe JB, Phan SH: Notch I signaling in FIZZI induction of myofibroblast differentiation. Am J Pathol 2009, 174: 1745-55.

FI000 Factor 8

Evaluated by Giulio Gabbiani 14 Apr 2009

19. Hinz B, Gabbiani G, Chaponnier C: The NH2-terminal peptide of alpha-smooth muscle actin inhibits force generation by the myofibroblast in vitro and in vivo. J Cell Biol 2002, I57:657-63.

FI000 Factor 6

Evaluated by Manfred Schliwa 17 Jun 2002

20. Horowitz JC, Rogers DS, Sharma V, Vittal R, White ES, Cui Z, Thannickal V]: Combinatorial activation of FAK and AKT by transforming growth factor-betal confers an anoikisresistant phenotype to myofibroblasts. Cell Signal 2007, |9:76|-7|.

21. Kulasekaran P, Scavone CA, Rogers DS, Arenberg DA, Thannickal VJ, Horowitz JC: Endothelin-I and transforming growth factorbeta I independently induce fibroblast resistance to apoptosis via AKT activation. Am J Respir Cell Mol Biol 2009, 41:484-93.

22. de Andrade JA, Thannickal VJ: Innovative approaches to the therapy of fibrosis. Curr Opin Rheumatol 2009, 21 :649-55.

23. Douglass A, Wallace K, Parr R, Park J, Durward E, Broadbent I, Barelle C, Porter AJ, Wright MC: Antibody-targeted myofibroblast apoptosis reduces fibrosis during sustained liver injury. J Hepatol 2008, 49:88-98.

FI000 Factor 6

Evaluated by Stuart Forbes 07 May 2008

24. Hinz B, Celetta G, Tomasek JJ, Gabbiani G, Chaponnier C: Alphasmooth muscle actin expression upregulates fibroblast contractile activity. Mol Biol Cell 200I, I2:2730-4I.
25. Varga J, Pasche B: Transforming growth factor beta as a therapeutic target in systemic sclerosis. Nat Rev Rheumatol 2009, 5:200-6.

26. Howell JE, McAnulty RJ: TGF-beta: its role in asthma and therapeutic potential. Curr Drug Targets 2006, 7:547-65.

27. Meier K, Nanney LB: Emerging new drugs for scar reduction. Expert Opin Emerg Drugs 2006, II:39-47.

28. Liu $X, H u H$, Yin JQ: Therapeutic strategies against TGF-beta signaling pathway in hepatic fibrosis. Liver Int 2006, 26:8-22.

29. Annes JP, Chen Y, Munger JS, Rifkin DB: Integrin alphaVbeta6mediated activation of latent TGF-beta requires the latent TGF-beta binding protein-I. J Cell Biol 2004, I65:723-34.

30. Jenkins RG, Su X, Su G, Scotton CJ, Camerer E, Laurent GJ, Davis GE, Chambers RC, Matthay MA, Sheppard D: Ligation of proteaseactivated receptor I enhances alpha(v)beta6 integrin-dependent TGF-beta activation and promotes acute lung injury. J Clin Invest 2006, I I6:1606-14.

31. Aluwihare $P$, Munger JS: What the lung has taught us about latent TGF-beta activation. Am J Respir Cell Mol Biol 2008, 39:499502.

32. Horan GS, Wood S, Ona V, Li DJ, Lukashev ME, Weinreb PH, Simon KJ, Hahm K, Allaire NE, Rinaldi NJ, Goyal J, FeghaliBostwick CA, Matteson EL, O'Hara C, Lafyatis R, Davis GS, Huang X, Sheppard D, Violette SM: Partial inhibition of integrin alpha(v)beta6 prevents pulmonary fibrosis without exacerbating inflammation. Am J Respir Crit Care Med 2008, 177:56-65.

33. Hahm K, Lukashev ME, Luo Y, Yang WJ, Dolinski BM, Weinreb PH, Simon KJ, Chun Wang L, Leone DR, Lobb RR, McCrann DJ, Allaire NE, Horan GS, Fogo A, Kalluri R, Shield CF 3rd, Sheppard D, Gardner HA, Violette SM: Alphav beta6 integrin regulates renal fibrosis and inflammation in Alport mouse. Am J Pathol 2007, 170: I I0-25.

34. Wang B, Dolinski BM, Kikuchi N, Leone DR, Peters MG, Weinreb PH, Violette SM, Bissell DM: Role of alphavbeta6 integrin in acute biliary fibrosis. Hepatology 2007, 46: I404-I2.

35. Patsenker E, Popov Y, Stickel F, Jonczyk A, Goodman SL, Schuppan D: Inhibition of integrin alphavbeta6 on cholangiocytes blocks transforming growth factor-beta activation and retards biliary fibrosis progression. Gastroenterology 2008, 135:660-70.

FI000 Factor 8

Evaluated by Domenico Alvaro 17 Jun 2008

36. Jenkins G: The role of proteases in transforming growth factor-beta activation. Int J Biochem Cell Biol 2008, 40:1068-78.

37. Margadant $C$, Sonnenberg A: Integrin-TGF-beta crosstalk in fibrosis, cancer and wound healing. EMBO Rep 2010, I I:97-105.

38. Tenney RM, Discher DE: Stem cells, microenvironment mechanics, and growth factor activation. Curr Opin Cell Biol 2009, $21: 630-5$.

39. Goodwin A, Jenkins G: Role of integrin-mediated TGFbeta activation in the pathogenesis of pulmonary fibrosis. Biochem Soc Trans 2009, 37:849-54.

40. Nishimura SL: Integrin-mediated transforming growth factorbeta activation, a potential therapeutic target in fibrogenic disorders. Am J Pathol 2009, 175:1362-70.

4I. Wipff PJ, Rifkin DB, Meister JJ, Hinz B: Myofibroblast contraction activates latent TGF-betal from the extracellular matrix. J Cell Biol 2007, I79: I3II-23.

FI000 Factor 10

Evaluated by Giulio Gabbiani 03 Jan 2008, Carol Otey 17 Jan 2008

42. Zhou Y, Hagood JS, Lu B, Merryman WD, Murphy-Ullrich JE: Thy-Iintegrin alphavbeta5 interactions inhibit lung fibroblast contraction-induced latent TGF-betal activation and myofibroblast differentiation. J Biol Chem 2010, 285:22382-93.

43. Scotton CJ, Krupiczojc MA, Königshoff M, Mercer PF, Lee YC, Kaminski N, Morser J, Post JM, Maher TM, Nicholson AG, Moffatt JD, Laurent G], Derian CK, Eickelberg O, Chambers RC: Increased 
local expression of coagulation factor $X$ contributes to the fibrotic response in human and murine lung injury. J Clin Invest 2009, I 1 9:2550-63.

FI000 Factor 9

Evaluated by Moisés Selman 07 Oct 2009, Valder Arruda 28 Oct 2009

44. Asano $\mathrm{Y}$, Ihn $\mathrm{H}$, Yamane $\mathrm{K}$, Jinnin $\mathrm{M}$, Tamaki $\mathrm{K}$ : Increased expression of integrin alphavbeta5 induces the myofibroblastic differentiation of dermal fibroblasts. Am J Pathol 2006, 168:499-510.

FI000 Factor 6

Evaluated by Giulio Gabbiani 28 Feb 2006

45. Bryant JE, Shamhart PE, Luther DJ, Olson ER, Koshy JC, Costic DJ, Mohile MV, Dockry M, Doane KJ, Meszaros JG: Cardiac myofibroblast differentiation is attenuated by alpha(3) integrin blockade: potential role in post-MI remodeling. J Mol Cell Cardiol 2009, 46:186-92.

FI000 Factor 6

Evaluated by Giulio Gabbiani 23 Jan 2009

46. Carracedo S, Lu N, Popova SN, Jonsson R, Eckes B, Gullberg D: The fibroblast integrin alphal Ibetal is induced in a mechanosensitive manner involving activin $A$ and regulates myofibroblast differentiation. J Biol Chem 2010, 285:10434-45.
47. Hinz B: Masters and servants of the force: The role of matrix adhesions in myofibroblast force perception and transmission. Eur J Cell Biol 2006, 85:175-8I.

48. Chan MW, Chaudary F, Lee W, Copeland JW, McCulloch CA: Forceinduced myofibroblast differentiation through collagen receptors is dependent on mammalian diaphanous ( $\mathrm{mDia}$ ). J Biol Chem 2010, 285:9273-8I.

49. Goffin JM, Pittet P, Csucs G, Lussi JW, Meister JJ, Hinz B: Focal adhesion size controls tension-dependent recruitment of alpha-smooth muscle actin to stress fibers. J Cell Biol 2006 , 172:259-68.

FI000 Factor 8

Evaluated by Giulio Gabbiani 17 Jan 2006

50. Small EM, Thatcher JE, Sutherland LB, Kinoshita H, Gerard RD, Richardson JA, Dimaio JM, Sadek H, Kuwahara K, Olson EN: Myocardin-related transcription factor-A controls myofibroblast activation and fibrosis in response to myocardial infarction. Circ Res 2010, 107:294-304.

5I. Clement S, Hinz B, Dugina V, Gabbiani G, Chaponnier C: The $\mathrm{N}$-terminal Ac-EEED sequence plays a role in alpha-smoothmuscle actin incorporation into stress fibers. J Cell Sci 2005, I 1 8:1395-404.

52. Aarabi S, Bhatt KA, Shi Y, Paterno J, Chang El, Loh SA, Holmes JW, Longaker MT, Yee H, Gurtner GC: Mechanical load initiates hypertrophic scar formation through decreased cellular apoptosis. FASEB J 2007, 21:3250-6I. 